\title{
The 1958 New York Convention on the Recognition and Enforcement of Foreign Arbitral Awards.
}

\author{
Abdelsalam Hammash \\ Associate Professor in international Law \\ School of Law, Middle East \\ Khaled AlShakhanbeh \\ Assistant Professor in Commercial Law \\ School of Law, Middle East University \\ Amman, Jordan.
}

\begin{abstract}
Arbitration has been preferred as a most convenient procedure to settle economic disputes to prevent legal procedures that may cause harmful conditions for prosperity and profits. Accordingly, the conclusion of the 1958 New York Convention has been the pinnacle of this new form of regulating between parties that may dispute on economic issues rather than relying on the traditional legal procedures. Basically, the Convention has been set up as an International Convention between contracting States to regulate the recognition and enforcement of International arbitral awards. Our research will analyze the provisions of the Convention and its limitations when it has to do with contracting States' national legal system.
\end{abstract}

Key-words: 1958 New York Convention, arbitration, economic disputes, foreign arbitral awards.

\section{INTRODUCTION}

More than 140 countries have signed the 1958 United Nations Convention on the Recognition and Enforcement of Foreign Arbitral Awards, known as the "New York Convention" under the auspices of the United Nations Economic and Social Council. On June 7, 1959, it came into force after the third ratification. ${ }^{1}$ It was planned to enhance the world business interests which tend to prefer arbitration for the settlement of their disputes. This is due to the flexibility, informality, and speediness that can be attributed to arbitration in comparison with judicial proceedings in the international scene. ${ }^{2}$ Furthermore, the Convention was intended to set the basis in respect of preventing discrimination between domestic and international arbitral awards in the contracting States concerning the issues of recognition and enforcement. ${ }^{3}$ It has been the most important instrument in the field of recognition and enforcement of foreign arbitral awards. The importance of the Convention derives from its far-reaching scope of application. ${ }^{4}$ Namely, the vast majority of States, under which their jurisdiction the international arbitration proceedings are held, are parties to the Convention. ${ }^{5}$ In particular,

\footnotetext{
1 K. W. Patchett in association with the Commonwealth Secretariat, The New York Convention on the Recognition and Enforcement of Foreign Arbitral Awards, Explanatory Documentation prepared for Commonwealth Jurisdictions, Commonwealth Secretariat, London June, 1981, p 3.

2 Ibid, p 6.

3 Ibid, p 7.

4 Jason Fry, 'Enforcement of the Award',

$<$ http://www1.fidic.org/resources/contracts/icc_apr04/icc27_jason_fry.asp>, accessed 2 June 2009.

5 Robert Merkin, Arbitration Law ( LLP, London 1991) p 19-16.
} 
most commercial nations are signatories to it as well. ${ }^{6}$ It has underpinned the international commercial arbitration by sitting up a universal minimum standard for recognition and enforcement of arbitral awards. ${ }^{7}$ We will first explore the provisions of the Convention concerning the recognition and enforcement of foreign awards and the recognition of arbitration agreements. In addition to reservations related to the scope of the Convention, reciprocity and commercial reservations. Moreover, the formality requirements are considered subsequently in this article.

\section{Recognition and Enforcement of foreign awards}

The requirements to have the recognition and/or enforcement of an arbitral award being granted are kept to the minimum in the New York Convention. ${ }^{8}$

\section{The requirements enforced on contracting States according to Article III.}

In pursuance with Article III, each contracting State is required to recognize arbitral awards as binding. Moreover, they are required to enforce these awards in accordance with the rules of procedure in each one of them (lex fori) under the umbrella of the Convention. The rules of procedure referred to in this Article are limited to matters such as the form of the application, competent authority, attachments in relation to enforcement, but the conditions of enforcement are, of course, those laid down in the Convention. ${ }^{9}$ In addition, they shall not impose more onerous conditions or higher fees on the recognition and enforcement of foreign awards to which the Convention applies more than those imposed in respect of the recognition and enforcement of national awards. ${ }^{10}$ It is worth mentioning that, a mere ratification of the Convention by a State does not always suffice for the provisions of the Convention to be applied in the State concerned. The latter must implement the Convention's provisions in its domestic legal system. ${ }^{11}$ Therefore, it appears that each State's domestic legal system will impact on the way each contracting State will enforce the Convention's provisions.

\section{The binding flexibility of the Convention due to the individuality of States' national legal system.}

It is clear that the New York Convention endorsed the diversity of rules of procedures among contracting States. Indeed, the Convention does not intend to establish uniformity among the methods of enforcement; rather, it does intend to create a uniform mechanism by which arbitral awards are made enforceable. ${ }^{12}$ However, such a reference to the rules of procedure in national laws which, of course, differ between States, may affect the harmonization required in the process of recognition and enforcement of foreign awards. Accordingly, it was considered as a shortcoming in the Convention. ${ }^{13}$

The flexibility of the Convention lies in Article VII (1). It does not preclude the operation of the favorable multilateral or bilateral agreements related to the recognition and enforcement of arbitral awards to which the contracting States are parties. Furthermore, the Convention does

\footnotetext{
6 Ibid, p 19-28.

7 Jason Fry (n 50).

8 Phillip Capper, International Arbitration: A Handbook (3rd ed.), LLP, London 2004) p 125.

${ }^{9}$ Albert Jan van den Berg, The New York Arbitration Convention of 1958: Towards a Uniform Judicial Interpretation (Kluwer Law and Taxation Publishers, Deventer 1981) pp 239-240.

10 Article III of the New York Convention.

11 Mauro Rubino-Sammartano, International Arbitration Law and Practice (2 ${ }^{\text {nd }}$ ed., Kluwer Law International, Hague, 2001), p. 947.

12 Andrew Tweeddale and Keren Tweeddale, A Practical Approach to Arbitration Law (Blackstone Press Limited, London 1999), p. 295.

13 This is according to Pieter Sanders, Robert Briner, and Albert Jan Van Den Berg, the 40 th anniversary of the Convention, see 'Enforcing Arbitration Awards under the New York Convention, Experience and Prospects', pp. 4, 9, 42. <http://www.uncitral.org/pdf/english/texts/arbitration/NY-conv/NYCDay-e.pdf> Accessed 3 June 2009.
} 
not preclude any interested party from any right he might have to benefit from an arbitral award by means of and to the extent allowed by the law or the treaties of the State in which such an award is sought to be relied upon. ${ }^{14}$ In other words, Article VII (1) gives permission to the party, who is looking for recognition and enforcement of an award, to avail itself from any other relevant agreements whether bilateral or multilateral and from the domestic law of the enforcement State. ${ }^{15}$

In fact, the interpretation of New York Convention' provisions varies among the Courts of contracting States. Courts of a few adhered States have sometimes interpreted widely the grounds for refusal recognition and enforcement laid down in Article $V$ of the Convention. As a result, the mere accession of a State to the Convention cannot be regarded nowadays as an absolute guarantee for the foreign creditor of the arbitral award to obtain recognition and enforcement in this State. Nevertheless, the vast majority of cases in relation to the recognition and enforcement of awards have been decided in a manner which grants recognition and enforcement of arbitral awards. ${ }^{16}$

\section{Formalities for recognition and enforcement of arbitral awards.}

The New York Convention stipulates some formalities to be satisfied by the party seeking the recognition and enforcement of an award. These formalities have been laid down in Article IV. Firstly, 'The duly authenticated original award or a duly certified copy thereof' shall be produced. Secondly, 'The original agreement referred to in article II or a duly certified copy thereof' shall be produced as well. ${ }^{17}$ Furthermore, if these documents are in a language other than the official one in the State of enforcement, a translation certified by an official or sworn translator or consular or diplomatic agent are to be enclosed with the application of recognition and enforcement. ${ }^{18}$ These formalities mentioned in Article IV are the only requirements the applicant party must comply with. ${ }^{19} \mathrm{~A}$ distinction between authentication and certification has been drawn by Van Den Berg as the following:"

The authentication of a document is the formality by which the signature thereon is attested to be genuine. The certification of a copy is the formality by which the copy is attested to be a true copy of the original. The authentication therefore concerns the signature, whilst the certification concerns the document as a whole." 20

Accordingly, while the authentication concerns with signatures, the certification concerns with the entirety of the copy and that it is a true one of the original. ${ }^{21}$

\footnotetext{
14 See Article VII(1) of the Convention.

15 Andrew Tweeddale and Keren Tweeddale, Arbitration of Commercial Disputes: International and English Law and Practice (OUP, New York 2005), p. 446.

16 Jeffrey M. Hertzfeld, 'Enforcement of Foreign Arbitral Awards: The International Framework', p 2. <http://www.steelbee.net/ENFORCEMENT\%200F\%20FOREIGN\%20ARBITRAL\%20AWARDS.pdf> accessed 2 June 2009.

17 Article IV of the Convention. See Dardana Ltd v Yukos Oil Co [2002] 2 Lloyd's Rep 326. In this case, the Court rejected the assertion of the respondent that, contrary to 5 of the English arbitration Act 1996, there was no written binding agreement to arbitrate. The Court of Appeal held that, in pursuance with s 102 of the mentioned Act, the applicant is required to produce only the award and the arbitration agreement or a duly certified copy of each of them. The Court maintained that it was sufficient if the party seeking enforcement produces a document that alleged to be the clause to arbitrate or if it produces terms in writing containing or referring to a clause to arbitrate. The Court concluded that whenever these requirements were met, the burden of proof would fall upon the resistant party to prove that it had not been a party to such agreement to arbitrate. Accordingly, Merkin illustrated that the applicant is not obliged to prove that the arbitration agreement is binding. See Robert Merkin (n. 51), pp. 19-47.

18 Andrew Tweeddale and Keren Tweeddale (n 58) p 295.

19 Albert Jan van den Berg (n 55) p 248.

20 Ibid, $\mathrm{p} 251$.

21 Ibid.
} 
In addition to the mentioned distinction, the interpretation of Article IV has resulted in many difficulties. Firstly, the issue of which is the law governing the authentication of the arbitral award and the certification of arbitral award and arbitration agreement. ${ }^{22}$ In this regard, the authentication and the certification can be either in accordance with the law of the State where the recognition and enforcement is sought or the law of the State where the award is made. ${ }^{23}$ However, the practice tends to prefer the law of the country in which recognition and enforcement have been sought. This is due to the tendency of the Courts to apply their law. ${ }^{24}$ Secondly, the matter concerning the question of which authority is capable to authenticate or certify. However, this matter depends on the law applicable to authentication and certification. Hence, by reference to the foregoing answer, it is sufficient for this authentication and certification to be undertaken by the diplomatic or consular agent of the country where the enforcement is sought which located in the country in which the award was made. ${ }^{25}$

Thirdly, when supplying a certified copy of the award, the original award should also be authenticated. This confusion came into existence since the term 'thereof' may refer to the original award or to the authenticated original award. In this context, an overview on the legislative history of the Convention reveals that the authentication is required only when producing the original award. Furthermore, the requirement to supply a copy of an authenticated original award is onerous and contrary to the spirit of the Convention which intended primarily to facilitate recognition and enforcement of foreign awards. ${ }^{26}$

It is worth mentioning that the failure to produce these documents listed in Article IV (1) is not conducive automatically to the dismissal of the enforcement request. Such a failure qualifies to be cured later during the proceedings. ${ }^{27}$ Furthermore, in terms of the certification of the translation, like the certification of the award and the arbitration agreement, this requirement may be satisfied according to either the law of the country in which the award was made or the country in which recognition and enforcement is sought. ${ }^{28}$. To sum up, despite the Convention at the first glance is deemed as dealing merely with foreign arbitration awards, however, it deals with arbitration agreements also. It places the contracting States under an obligation to recognize and enforce arbitration agreements. ${ }^{29}$ Furthermore, these reservations permitted to the contracting States to declare have the effect of restricting the scope of the Convention. In particular, the commercial reservation has resulted in many problems regarding the definition of the term 'commercial' which differs from State to State.

\section{Recognition of Arbitration Agreements}

The Convention deals with the recognition of arbitration agreements in addition to its prime purpose that is, recognition and enforcement of foreign arbitral awards.

\section{The provisions of Article II in the recognition of foreign arbitral awards.}

Article II (1) of the Convention has placed the contracting States under an obligation to recognize written agreements under which the parties assumes to submit to arbitration, "all or any differences which have arisen or which may arise between them in respect of a defined legal relationship, whether contractual or not, concerning a subject matter capable of

29 Alan Redfern and Martin Hunter, (n. 80) p 523. 
settlement by arbitration." ${ }^{30}$ Nonetheless, the contracting States can limit this obligation to those arbitration agreements dealing with commercial relationships by virtue of Article I (3). This provision was intended to secure the enforcement of awards. This is by guaranteeing that an award will not be refused enforcement on the ground of refusing the recognition of the agreement it has arisen out from. ${ }^{31}$ Article II (2) deals with the term 'agreement in writing'. It comes within its ambit, an arbitral clause included in a contract or in an arbitration agreement signed by the parties or contained in exchanged letters or telegrams. Undoubtedly, the mentioned examples are not exhaustive. For instance, the term 'agreement in writing' is suggested to extend to cover a contract which refers to a standard set of sale conditions. ${ }^{32}$

In accordance with Article II (3), it seems that this obligation to recognize agreements is operative in relation to matters concerning the staying of judicial proceedings whenever arbitration agreement exists. ${ }^{33}$ This obligation to stay proceeding does not require a standing submission of a dispute to arbitration. In other words, the Court must refer the parties to arbitration even though the submission of the dispute to arbitration has not yet taken place. ${ }^{34}$ However, this duty is qualified by conditions. Firstly, a request must be submitted to the Court by one of the parties for such a stay which indicates that there has been an agreement on the matter to be referred to arbitration. Secondly, this request must be at the time while an action is pending before the Court. Thirdly, the arbitration agreement must be related to a subject matter that is capable of being settled by arbitration.

However, the Convention is silent on the issue of which law is competent to determine the capability of settlement by arbitration. ${ }^{35}$ It seems by inference from Article V (2)(a) ${ }^{36}$ that it is the law of the Court before which the request is made (lex fori). ${ }^{37}$ By contrast, the Court can decline recognition of an agreement if it is involved in a subject matter which is not capable of arbitration under its law. Fourthly, the arbitration agreement upon which the parties to be referred to arbitration must not be null and void, inoperative or incapable of being performed. The Convention is also silent on the issue of the law under which the determination of these matters should be..$^{38}$ By surveying Article $V(1)(a)$, it is clear that the law of the parties is to determine the validity of the agreement. Where such a choice is absent, the conflict of law rules in the laws of the Court is to determine the validity of the agreement. However, so far as a matter of public policy is involved, the law of the Court is to command. But these matters related to the applicable law where the Convention is silent are not devoid of doubt. ${ }^{39}$

The argument to put forward in this context is whether the term 'arbitration agreements' includes both domestic and international (foreign) agreements. In this regard, some argue that Article II of the Convention was intended primarily to maintain and enhance the automatic validity of the arbitration agreements. It follows that, since the term 'agreements' is

\footnotetext{
30 Article II(1) of the New York Convention.

31 K. W. Patchett in association with the Commonwealth Secretariat (n 47) p 14.

32 Ibid.

33 Article III (3) of the New York Convention provides that: The Court of a Contracting State, when seized of an action in a matter in respect of which the parties have made an agreement within the meaning of this article, at the request of one of the parties, refer the parties to arbitration, unless it finds that the said agreement is null and void, inoperative or incapable of being performed'.

34 K. W. Patchett in association with the Commonwealth Secretariat (n 47) p 17.

35 Ibid, p 16.

36 Article $\mathrm{V}(2)$ (a) reads as the following: 'Recognition and enforcement of an arbitral award may also be refused if the competent authority in the country where recognition and enforcement is sought finds that: (a) The subject matter of the difference is not capable of settlement by arbitration under the law of that country; or (b)....'

$37 \mathrm{~K}$. W. Patchett in association with the Commonwealth Secretariat (n 47) p 16.

38 Ibid.

39 Ibid, pp 16-17.
} 
unconditional, it appears that the Convention was intended to cover all arbitration agreements irrespective whether domestic or international, provided they satisfy the requirements stipulated in the Convention. ${ }^{40}$

However, it is admitted that, taking as a premise the prime purpose of the Convention which has been addressed to foreign arbitral awards, this Article should be interpreted in a manner that covers only international agreements. This is because of the fact that domestic arbitration agreements must be cured in respect of staying proceedings in domestic laws, particularly, in the laws of Courts procedures regulating proceedings and hearings before Courts.

\section{The recognition of arbitral awards according to the Convention's provisions.}

The Convention shall apply the recognition and enforcement of arbitration awards made in States other than the State where the recognition and enforcement is sought, notwithstanding whether the State in which the award was made is a contracting State or not. Also, it shall apply to those arbitral awards not categorized as domestic in the State where the recognition and enforcement is sought. This situation arises when the arbitration proceedings are labeled as non-domestic in the State of enforcement, for example, when the rules of procedure of other States are applied to the arbitration proceedings. These awards must have resulted from differences between persons whether physical or legal. And in appropriate cases, the Convention may extend to cover differences between States or corporations. ${ }^{41}$ In addition, such awards are covered by the application of the Convention irrespective of whether they are made by an ad hoc arbitration in which arbitrators are appointed case-by-case or they are made by permanent arbitral bodies. However, it is admitted that the appointment of arbitrators or the submission to permanent arbitral bodies by parties, as the case might be, must be voluntary and deriving from the agreement of the parties. ${ }^{42}$

In the context of the determination of the place where the award is made, under the previous English Arbitration Act of 1975 implementing the Convention into English law, a 'Convention award' was that one which had been made in the territory of a State other than the United Kingdom, which is party to the Convention. ${ }^{43}$ This issue of defining the place of making an award was brought before the House of Lords in Hiscox v. Outhwaite (No 1). ${ }^{44}$ This case was concerning an entire English arbitration. It was held in England between Lloyd's underwriters and directed by a member of the bar. On the basis of that, the award was signed by the arbitrator in France and that the signature drew up the final mind of the arbitrator, the House of Lords maintained that the award had been made in France. The outcome was that an award entirely made in England, except signing it, was a French award. ${ }^{45}$ However, the English Arbitration Act has redressed this result by providing that the place of the seat of arbitration is to be considered as the place where the award was made. ${ }^{46}$

\footnotetext{
40 Mauro Rubino-Sammartano (n 57), p. 948.

41 Article I (1) of the New York Convention. See also, K. W. Patchett in association with the Commonwealth Secretariat (n. 47), pp. 18-19.

42 Article I (2) of the New York Convention. See also K. W. Patchett in association with the Commonwealth Secretariat (n. 47), p. 20.

43 English Arbitration Act 1975 (c.3) General s 7(1).

44 Hiscox v. Outhwaite (No 1) [1991] 3 All ER 641; [1991] 2 Lloyd's Rep. 435.

45 Robert Merkin (n. 51), pp. 19-28.

46 English Arbitration Act, s.100 (2) (b) provides for: ' an award shall be treated as made at the seat of the arbitration, regardless of where it was signed, dispatched or delivered to any of the parties.'
} 
Regarding the scope of the Convention, Redfern and Hunter have commented on the initial Statement of the Convention as it represents 'a strikingly international attitude'.47 Article I (1) of the Convention provides for a general and broad scope of application. However, this broad application of the Convention might be confined by allowing States acceding to the Convention to adopt reciprocity or/and commercial reservations. ${ }^{48}$

\section{Reservations about the application of New York Convention}

The wide scope of application of the New York Convention to these awards Stated in Article I (1) is restricted by two reservations. Article I (3) of the Convention has left the door open for signatory States to qualify their obligations under the Convention to recognize and enforce foreign awards. These two reservations are reciprocity reservation and commercial reservation. ${ }^{49}$ In addition to their restrictive effect, the unsuccessful party may rely on these reservations to oppose recognition and enforcement proceedings. Hence, where any of these reservations is declared by the State in which recognition and enforcement is sought, the unsuccessful party may rely on this reservation assumed by the State to resist enforcement. However, both reservations should be taken under consideration when choosing the State where the arbitration is to be held, and when expecting the award is where to be enforced. ${ }^{50}$

\section{The principle of reciprocity}

The reciprocity reservation refers to the authorization of a contracting State to declare that it is going to apply the Convention on the recognition and enforcement of only those arbitral awards made in the territory of a contracting State. ${ }^{51}$ By contrast, an adoption of such reservation by a signatory State means that the State need not to recognize and/or enforce arbitral awards which have been made in a non-contracting State. ${ }^{52}$ The justification for such an authorization might be that the declaring State intends to confine the application of the Convention only to those awards made in the contracting States that under the Convention are coerced to recognize and enforce awards made in the declaring State..$^{33}$ Accordingly, if such a reservation is not made, it seems that the contracting State should recognize and enforce awards made in non-contracting States as part of its obligation under the Convention towards contracting States. Moreover, even if the reciprocity reservation is declared by a contracting State it will still be open for this State to adopt its own legislations according to which it may recognize and enforce awards made in a non-contracting State and impose additional requirements in this regard. ${ }^{54}$

\section{The problematic labeling of 'commercial relationship'}

This reservation refers to the limitation of the Convention to include only foreign awards resulting from relationships that are considered as commercial under the law of the State which has adopted such reservation. ${ }^{55}$ This provision was modeled to accommodate with some civil law countries which still distinguish between commercial and non-commercial litigation. ${ }^{56}$ Indeed, this reservation shed light on a problem. The standardizations according to which a

\footnotetext{
47 Alan Redfern and Martin Hunter, Law and Practice of International Commercial Arbitration (4th ed., Sweet \& Maxwell, London 2004) p. 523.

48 Ibid, p. 524.

49 See Article I(3) of the New York Convention. See also Andrew Tweeddale and Keren Tweeddale (n 58) p 293.

50 Phillip Capper (n 54) pp 132-133.

51 Article I(3) of the Convention.

52 Andrew Tweeddale and Keren Tweeddale (n 58) p 293.

53 K. W. Patchett in association with the Commonwealth Secretariat (n 47) p 13.

54 Ibid, p 19.

55 Article I(3) of the New York Convention.

56 Jeffrey M. Hertzfeld (n 62) p 5.
} 
relationship might be labeled as commercial are different among the domestic laws of States. ${ }^{57}$ A relationship which categorized as commercial according to the law of a contracting State might not be categorized so in the law of other contracting States. In fact, this has led to affect negatively the uniformity needed in the interpretation of the Convention. ${ }^{58}$ Moreover, the interpretation of the term commercial may cause difficulties within the contracting State itself. For example, India entered into New York Convention on the basis of the commercial reservation. In Indian Organic Chemical Ltd v Subsidiary 1 (US) Subsidiary 2 (US) and Chemtex Fibres Inc (Partner Company) (US) ${ }^{59}$ an application brought before the High Court of Bombay to stay proceedings that had been commenced in spite of an arbitration agreement had been existent. In pursuance of the Indian law implementing the Convention, the Court must stay proceeding if the arbitration agreement falls within the scope of the New York Convention. The Court concluded that the agreement under which the dispute had arisen could not be regarded as commercial by virtue of the relevant Indian law despite of its commercial nature. The judge concluded as the following:"

In my opinion, in order to invoke the provisions of [the Convention], it is not enough to establish that an agreement is commercial. It must also be established that it is commercial by virtue of a provision of law or an operative legal principle in force in India ${ }^{60 . "}$

By contrast, this approach was rejected by the High Court of Gujarat in Union of India and Ors $v$ Lief Hoegh \& Co (Norway) ${ }^{61}$. The same situation was standing before the Court. Nonetheless the Court granted such a stay of proceedings. The judge held that the term 'commerce' is a:"

word of the largest import and takes in its sweep all the business and trade transactions in any of their forms, including the transportation, purchase, sale and exchange of commodities between the citizens of different countries. ${ }^{62 "}$

Consequently, this reservation has created problems in the application of the Convention. It is admitted that such an allowance to enter this reservation may restrict the scope of the Convention to a lesser level. Of course, this will have the effect of encompassment and will subvert the essence of the Convention. Hence, it would have been worthier if the drafter of the Convention had laid down even general principles concerning the commercial relationships to secure a minimum consistency in this regard.

\section{CONCLUSION}

The New York Convention has paved the way to arbitration as an innovative and more appropriate procedure to settle economic disputes, and more important, it has set up a global procedure to contracting parties on the basis of foreign arbitral awards. Indeed, the articles of the Conventions stipulate the provisions under which the recognition of arbitral awards might be possible and be enforced in case of commercial disputes. The Article III frames the conditions in which the contracting States have to implement the Convention's provisions in their national legal system. Therefore, a challenging situation arose since each State, which relies on its national legal system, will interpret the provisions in a particular way in terms of recognition and enforcement of awards. Therefore, the Convention has appeared disappointingly to be a flexible tool in the interpretation of provisions within the domestic

\footnotetext{
57 Mauro Rubino-Sammartano (n 57) p 947.

58 ALAN REDFERN and MARTIN HUNTER (n 80) p 525.

59 Indian Organic Chemical Ltd v Subsidiary 1 (US) Subsidiary 2 (US) and Chemtex Fibres Inc (Partner Company) (US) (1979) IV Ybk Commercial Arbitration 271.
} 
legal corpus. At the same time, much has to be said on the formalities especially concerning authentication and certification; indeed, the Article IV leaves ambiguity on the meaning of these two terms and the issue of these specific documents might be problematic in some procedures in terms of publication and cost of issue. Along with this, the study of the provisions on the recognition of arbitral awards points out the determination of the place where the award is made. For example, the English Court postulated that the seat of arbitration was the place where the award had been made. Finally, the limitations of the New York Convention articulated around two axes. In one hand, the principle of reciprocity between contracting and non-contracting parties is not respected. On the second hand, the problematic of labeling 'commercial relationships' is due to the difference among States' domestic laws. These drawbacks may have a restrictive effect and allow opposing parties to impede the arbitration to proceed.

\section{References}

Capper, Phillip, (2004). .International Arbitration: A Handbook. (3 ${ }^{\text {rd }}$ ed.), LLP, London. Fry, Jason, 'Enforcement of the Award', <http://www1.fidic.org/resources/contracts/icc_apr04/icc27_jason_fry.asp>, accessed 2 June 2009.

Hertzfeld, Jeffrey M., 'Enforcement of Foreign Arbitral Awards: The International Framework', <http://www.steelbee.net/ENFORCEMENT\%200F\%20FOREIGN\%20ARBITRAL\%20AWARDS.pdf> accessed 2 June 2009.

Jan van den Berg, Albert, (1981). The New York Arbitration Convention of 1958: Towards a Uniform Judicial Interpretation. Kluwer Law and Taxation Publishers, Deventer.

Merkin, Robert, (1991). Arbitration Law, LLP, London.

Patchett, K. W., in association with the Commonwealth Secretariat, The New York Convention on the Recognition and Enforcement of Foreign Arbitral Awards, Explanatory Documentation prepared for Commonwealth Jurisdictions, Commonwealth Secretariat, London, (June 1981), p. 3.

Redfern, Alan, Hunter, Martin (2004). Law and Practice of International Commercial Arbitration. (4 ${ }^{\text {th }}$ ed.), Sweet \& Maxwell, London.

Rubino-Sammartano, Mauro, (2001). International Arbitration Law and Practice (2 ${ }^{\text {nd }}$ ed.). Kluwer Law International, Hague.

Sanders, Pieter, Briner „,Robert and Jan Van Den Berg, Albert, the $40^{\text {th }}$ anniversary of the Convention, see

'Enforcing Arbitration Awards under the New York Convention, Experience and Prospects', pp. 4, 9, 42.

<http://www.uncitral.org/pdf/english/texts/arbitration/NY-conv/NYCDay-e.pdf> Accessed 3 June 2009.

Tweeddale, Andrew and Tweeddale, Keren, (1999). A Practical Approach to Arbitration Law. Blackstone Press Limited, London.

(2005). Arbitration of Commercial Disputes: International and English Law and Practice. OUP, New York.

Article I (3) of the Convention.

Article II (1) of the New York Convention.

Article III (3) of the New York Convention.

Article VII (1) of the Convention.

Article IV of the Convention.

Dardana Ltd v Yukos Oil Co [2002] 2 Lloyd's Rep 326.

English Arbitration Act 1975 (c.3) General s. 7(1).

Hiscox v. Outhwaite (No 1) [1991] 3 All ER 641; [1991] 2 Lloyd's Rep. 435.

Indian Organic Chemical Ltd v Subsidiary 1 (US) Subsidiary 2 (US) and Chemtex Fibres Inc (Partner Company) (US) (1979) IV Yearbook, Commercial Arbitration 271.

Union of India and Ors v Lief Hoegh \& Co (Norway) (1984) IX Ybk Commercial Arbitration 405. 